\title{
The Influence of the Globalization of COVID-19 Epidemic on China's Inflation
}

\author{
Xiaohang Chen \\ Nottingham University Business School, University of Nottingham Ningbo China, NingBo, 315100, China \\ Corresponding author's Email: 2056267636@qq.com
}

\begin{abstract}
The COVID-19 virus has a worldwide impact due to its strong spreading ability, and has a profound impact on inflation in countries around the world. This article analyzes the impact of inflation in China from the perspective of aggregate demand and short-term aggregate supply. On this basis, China's response to the globalization of the epidemic should focus on three aspects: encouraging online office, ensuring food production, and maintaining the stability of the supply chain.
\end{abstract}

Keywords: Covid-19, Inflation, China

\section{INTRODUCTION}

The Covid-19, which is still spreading around the world, has become a major obstacle to current world economic growth. Although China has effectively controlled the epidemic and handed over a perfect policy plan to face the epidemic, there are still a large number of countries that have not adopted similar effective epidemic prevention measures, such as the United States, India, and European countries. Their leaders feared that the economy would be hit and that national conditions refused to adopt strict epidemic prevention measures. As a result, it has been a year and a half since the domestic epidemic is still in a dangerous situation. The Chinese government did not consider shortcuts in terms of epidemic control. Once an infected person is found in a place, all the people will be screened, and the organization will be quickly mobilized. A large number of temporary hospitals have been built to treat patients infected with the new crown epidemic. At the same time, the exemption of treatment costs for domestic patients reduces the risk of infection and death caused by the inability to pay for medical expenses. China step up the development of a variety of new crown vaccines, and many Chinese vaccines have been certified effective by the WHO. As of July 7, 2021, the number of vaccinations nationwide has reached 13,42381 million doses.

In 2020, the total GDP of China was 101598.62 billion yuan, an increase of only $2.3 \%$ compared with last year. Due to the obvious impact of the epidemic in the first quarter of 2020 , GDP fell by $6.8 \%$ compared with the same period last year. However, in the following three quarters, there was a relatively large increase in the same period. According to data from the World Bank, the world's GDP fell by $3.595 \%$ in 2020 . China's growth against the trend under the pressure of the global economic recession is mainly attributed to strict anti-epidemic measures. At the beginning of 2020, the domestic consumer price index for food, tobacco and alcohol fluctuated greatly by more than $3 \%$ for two consecutive months.

This article focuses on the indicator of inflation during the globalization of the epidemic. BWCHINESE (2021)[1] states that during the epidemic, various countries have introduced various relief policies and adopted loose monetary policies in order to stimulate the economy, leading to a significant increase in inflation in various countries. For example, the U.S. CPI in May 2021 surged to 5\% year-on-year, which is close to the level of $5.3 \%$ during the U.S. subprime mortgage crisis and financial crisis in August 2008. You know, since March last year, within 58 weeks, including the economic package announced by the United States, the U.S. Treasury Department and the Federal Reserve have printed up to 30 trillion U.S. dollars in base currency liquidity, balance sheet purchases, and purchases.

As the systemic financial risks that abnormal inflation may bring are relatively large and must be guarded against, this article hopes to be used as a reference in future research. First of all, what is inflation? 
According to the classical inflation theory from Mankiw(2013) [2]: if the amount of money that exceeds the balance point of the current price level and the money supply is injected into a market, the inflation rate will rise. In addition, it has not affected the production of the production side, such as human resources, natural resources, technology, etc., there has not been a big change, which means that the number of goods supplied in a short period of time will not change significantly. At this time, the supply of money is greater than the demand. Then prices rise, and the inflation rate rises. Today, the COVID-19 pandemic is still raging around the world and has a greater impact on society's resumption of work and production. Productivity is lower than in the same period in previous years, which has increased the level of inflation. This article includes: responding to the cyclical financial crises and inflation of the capital society, helping to understand how to deal with inflation. How to deal with the impact of the globalization of the epidemic on China's inflation. Additionally, proposed plans that countries could mention in the face of the same dilemma in the future

\section{THE INFLUENCE OF COVID-19 ON CHINESE INFLATION}

\subsection{Trends in Chinese price levels during the epidemic}

According to the CPI data of the National Bureau of Statistics of China from January 2020 to June 2021, when the epidemic broke out in China (January and February 2020), CPI increased rapidly, but after March entered the CPI began to decline and entered a contraction. The contracted state lasted for 4 months. In January and February 2020, the price of food, tobacco, and alcohol rose rapidly. Each month, the increase was about 3\% year-on-year. During the period of the epidemic, the shortage of materials, whether it is epidemic prevention materials or food, has a large gap., Demand exceeds supply, leading to rising prices. In addition, the prices of food, tobacco, alcohol, and alcohol have been severely affected, rising by $15 \%$ to $16 \%$ in January and February over the same period of 2019, which was severely affected by the epidemic.

\subsection{Causes analysis}

\subsubsection{Aggregate demand}

On the whole, it seems that aggregate demand has remained relatively stable during the epidemic. The total demand is mainly composed of consumption (C), investment (I), government purchases (G), and net exports (NX). According to Mankiw Economics, except that government purchases are fixed by policies, the other three parts are all determined by economic conditions, especially the price level. During the severe period of the domestic epidemic in China, the main period will be from January to late March 2020, and a total of more than 80,000 people have been diagnosed.

First of all, from the consumer side, food consumer demand remains unchanged, but considering people's pessimistic attitude towards future epidemic prevention and control during the initial epidemic period, people are likely to hoard a large amount of food and other daily necessities to protect their lives for a period of time in the future. Then the consumption increases at this time. However, in entertainment and another aspect, due to strict epidemic prevention and control measures and people's negative psychological service industries such as catering and movie theaters, they have suffered severely.

Secondly, the investment situation shows that global investment has shrunk under the epidemic situation, mainly to prevent the epidemic from affecting the safety of personnel and causing communication and freight to be affected. Multinational companies mostly use online communication methods, and at the same time, due to different information technology strengths in different regions, communication is not smooth. According to Tian and $\mathrm{Li}$ (2020) [3], the global spread of the epidemic has affected the global supply chain, and the entire supply chain will be greatly affected due to one end. Produce goods, etc. As a result, investors lose confidence in this and reduce investment.

Looking back at government purchases, during the epidemic, the Chinese government invested in the purchase of a large number of epidemic prevention materials and the construction of various shelter hospitals for the prevention and control of the epidemic. Total government expenditure in 2020 will increase by $2.8 \%$ compared to 2019 , while fiscal revenue will be reduced by $3.9 \%$. Taxes and burdens will be reduced during the epidemic.

Finally, let's discuss net exports. In 2020, net exports will reach RMB 2.65 trillion, an increase of $132.8 \%$ year on year. This is mainly due to the export of epidemic prevention materials after the domestic epidemic has stabilized in the second half of the year. At the same time, it is difficult to resume work and resume production due to improper control of foreign epidemics. A large number of materials need to be supplied by China. For example, in March 2020, the United States reduced its statutory deposit reserve ratio to 0 , which means that the dollar currency multiplier is close to infinity, which greatly facilitates the disorderly expansion of the dollar on a global scale. The Fed issued 4.5 trillion U.S. dollars. Although it only circulates in the domestic market, for the time being, the U.S. dollar's status as an international currency has led to rapid circulation of the U.S. dollar in the international market. This has further led to a decline in the credit of U.S. dollar bonds and repayment defaults may lead to a 
large number of countries selling U.S. bonds, making the U.S. domestic CPI index remain high at more than $5 \%$. However, the consequences did not appear quickly. Nearly a year later, with the gradual printing of a large number of money, the CPI index will continue to reach more than $5 \%$ in May, June, and July of 2021. At the same time, due to the increase in my country's exchange rate, large exports to the United States have led to imported inflation in United States. Rising domestic prices in the United States have triggered people to buy low-priced products imported from China and stimulated Chinese export trade. In general, consumption has remained unchanged, investment has declined slightly, government purchases have risen slightly due to policy adjustments affected by the epidemic, but net exports have risen. So overall domestic demand remains stable and unchanged.

\subsubsection{Aggregate supply}

On the whole, the short-term total supply has fallen. The short-term aggregate supply mainly depends on the supply of labor, capital, and natural resources, as well as the available technologies for turning these factors of production into goods and services. First of all, labor factors. Most people affected by the epidemic cannot go out to work. This has a considerable impact on physical industries, such as manufacturing and catering, and labor cannot participate in labor. Looking at the dynamics of capital again, capital has been in a downturn at the beginning of the outbreak, mainly pessimistic about the future development of the epidemic and being impacted by the offline physical industry. The supply of natural resources has declined due to insufficient manpower to develop, purchase, and process. Affected by the epidemic, it is difficult to organize manpower to develop new technologies and carry out effective work in the process of technology transformation. In the end, supply is always inseparable from changes in cost factors. During the epidemic, the mobility of transnational labor has declined and unit labor costs have risen. The cost of working in various industries has risen, and the supply side is limited by cost to reduce production. Therefore, the short-term total supply is affected by rising costs, reduced labor, and reduced capital.

\section{SUGGESTIONS FOR RESPONDING TO THE GLOBAL EPIDEMIC}

\subsection{Encourage online office}

First of all, due to the difficulty in conducting offline work and gathering office during the epidemic period, many Internet companies and schools have launched online offices and lectures. Ge(2021) [4] report on industry opportunities under the new crown epidemic proposed that online office learning will become new industry needs. Due to the development of mobile devices and communication technology, the large-scale online office has become a reality. At the same time, it can save more costs for both the company and the workers. For the company, it saves the water and electricity bills for employees to work in the company. Work has a higher degree of freedom and a more comfortable office environment than under the supervision of the company's leaders, which helps to improve the enthusiasm and work efficiency of employees. At the same time, it saves the time and cost of commuting for workers.

\subsection{Guarantee of food materials}

During the epidemic, one of the most important elements to ensure is how people who comply with epidemic prevention measures at home can obtain or ensure that everyone has enough food. When there is a sufficient supply of food and materials on the market, it will not lead to the phenomenon of driving up prices and hoarding, thereby maintaining the stability of prices and stabilizing inflation. According to a report from China Economic Net [5]: In China, grain and wheat reserves can guarantee a year's supply of people across the country. This steadily guarantees the people's jobs without causing panic.

In terms of prices, the Chinese government has been taking reasonable measures to limit the disorderly growth of food prices. In terms of food procurement, the government's unified procurement prices have ensured the stability of food prices. Escorted the food market. In terms of food purchases by the general public, the panic caused by the epidemic caused people do not to want to go out for offline purchases, resulting in strong demand for online purchases, especially contactless delivery. According to Singapore's Channel News Asia, online purchases of agricultural products by residents under 25 years of age during the epidemic in China increased by $250 \%$, and residents over 55 years of age increased by $400 \%$. And such an increase can be satisfied mainly by relying on a large number of food supply outlets built in the city and a mature and stable online consumption platform.

At the same time, a sufficient vegetable food supply can be guaranteed in every major city. According to the response plan to ensure global food supply during the COVID-19 epidemic published by FAO Chief Economist Maximo Torero Cullen. Cullen (2020) [6] mentioned that the supply should be fully guaranteed. The supply chain is stable and smooth while ensuring the cleanliness and independence of warehouses and wholesale markets to avoid additional losses caused by the invasion of the COVID-19 virus. 'The Vegetable Basket' policy implemented by the Chinese government played a very important role during the epidemic. Chinese mayors are required to ensure the supply and 
safety of non-grain foods, especially fresh agricultural products, and meat.

\subsection{Stabilize supply chain}

Ensuring the stability of the logistics supply helps to ensure that the market is stable and there will be no increase in prices caused by material shortages so as to stabilize inflation. Solving logistics supply can be solved from four aspects. The first is to ensure the supply of labor. If the supply of personnel is sufficient, it is necessary to properly guarantee the wages and benefits of personnel. The government will provide subsidies to related companies in special periods, and banks will appropriately relax loan thresholds to ensure that related logistics companies survive the difficulties. Secondly, strengthen the safety education of logistics supply personnel and epidemic prevention and control education to prevent accidental infections and ensure the safety of the supply chain. Furthermore, the health department must strengthen the quarantine and inspection of logistics products to prevent a new round of potential infections caused by the virus attaching to the packaging. Finally, according to Ba and Bai (2020) [7], the Chinese government encourages banks to develop online and offline business service capabilities in terms of guaranteeing the financing of logistics during the epidemic, which plays a big role under the constraints of not being able to meet offline during the epidemic. . Support the innovative development of supply chain finance, and further ensure that import and export businesses are not affected by the shortage of funds. Stable logistics supply can effectively ensure sufficient supply of materials on the market and lower transportation costs can effectively resist rising prices, thereby avoiding inflation.

\section{CONCLUSION}

In response to the predicament of resisting the increase in inflation caused by rising prices during the epidemic, suggestions were mainly made to improve it from three aspects, so that the CPI during the epidemic was maintained in a moderate and stable range. Speaking of the online office, online office generally saves costs for the company and helps employees avoid the risk of COVID-19 virus infection that may be brought by gathering offices while developing new technologies to maintain the stability and reliability of online office. At the same time, through attempts during the epidemic, a template for future online work has been created, creating new markets and economic growth points. The second aspect is about ensuring the people's food and other materials during the epidemic. Because The Vegetable Basket policy adopted by the Chinese government for a long time has fully guaranteed the needs of the people in terms of non-grain foods and has been promoted by the United Nations Food and
Agriculture Organization. At the same time, a large amount of grain storage is also an important part. China has a considerable reserve of grain to ensure that market demand will not cause panic caused by food shortages. At the same time, we will severely crackdown on the behavior of deliberately driving up prices by taking advantage of the people's panic to ensure stable prices. Moreover, during the epidemic, people are reluctant to go to offline stores, and a large amount of demand is met through online platforms. This requires the stability and safety of logistics channels and higher technical requirements for online platforms. The third point is to ensure the stability of the supply chain. Banks can relax the loan requirements for companies engaged in the supply chain industry under risk control to help relevant companies tide over the difficulties. The government also provides policy assistance for them, and the financial industry also develops. Shanghai Service provides assistance to the transnational import and export industry. The limitation of this article is that it only discusses three parts to maintain price stability and ensure the stability of inflation. However, inflation changes cover a large number of influencing factors. Future research can be through discussions on employment, exchange rates, and monetary policy.

\section{REFERENCES}

[1]BWC (2021) The United States: China has repeatedly dumped US debts and has run out of ammunition, and the United States may snatch it in the near future BWCHINESE 7 September [online]. Available at:https://baijiahao.baidu.com/s?id=170470530994 9559581\&wfr $=$ spider\&for $=p c \quad$ [Accessed 2 September 2021]

[2]Mankiw, N.G. (2013) Principles of economics 8th ed. Boston: Cengage Learning

[3]Tian S.H. and Li X.Y. (2020) The Impact of the Global Spread of the New Crown Epidemic on China's Open Economy and the World Economy [online]. Available at: http://www.cnki.com.cn/Article/CJFDTotalHSYJ202004013.htm [Accessed 2 September 2021]

[4]Ge, S.J. (2021) Industries under the new crown epidemic. Modern Commercial Banking: pp. 14-19.

[5]Liu, H. and Qiao J.L. (2020) Under the epidemic, can China ensure food security? Economic Daily China Economic Net 7 April [online]. Available at:http://news.cau.edu.cn/art/2020/4/7/art_8779_66 9606.html [Accessed 2 September 2021]

[6]Cullen, M.T. (2020) Food and Agriculture Organization of the United Nations A battle plan for ensuring global food supplies during the COVID-19 crisis [online]. Available at: 
http://www.fao.org/news/story/zh/item/1268321/ic ode/. [Accessed 2 September 2021]

[7]Ba, S.S. and Bai, H.F. (2020) Covid-19 pandemic as an accelerator of economic transition and financial innovation in China Journal of Chinese Economic and Business Studies Volume 18, 2020 - Issue 4: Covid-19 special section The Impact of Covid-19 and Post Pandemic Recovery: China and the World Economy Pages 341-348. Available at:https://www.tandfonline.com/doi/full/10.1080/1 4765284.2020.1855394 [Accessed 2 September 2021] 